\title{
Free-Living Plant-Parasitic Nematodes do not Affect the Efficiency of Seed Tuber Fungicide Treatment against Rhizoctonia solani
}

\author{
Eva $\operatorname{Edin}^{1}$ (D) Maria Viketoft ${ }^{2}$ \\ Published online: 11 January 2017 \\ (C) The Author(s) 2017. This article is published with open access at Springerlink.com
}

\begin{abstract}
Stem canker on germinating potato sprouts is often caused by seed-borne inoculum of the fungus Rhizoctonia solani. However, high amounts of freeliving plant-parasitic nematodes have been found in field patches of potato plants with stem canker. Fungicide treatment of the seed tubers can be used to avoid stem canker caused by seed-borne inoculum but it is unknown if nematodes can affect this. To investigate whether free-living plant-parasitic nematodes, the root-lesion nematode Pratylenchus penetrans or a combination of several plant-parasitic nematode genera in a full nematode community, may have a negative effect on the fungicide seed treatment, a pot experiment with seed tubers inoculated with $R$. solani, half of which were treated with fungicides, was performed. The seed-borne inoculum caused severe damage to the plants, while no fungal damages were observed on the fungicide treated plants. This shows that the nematodes did not affect the fungicide treatment. The probability of black scurf decreased in treatments with a full nematode community, which may be due to the action of fungal-feeding nematodes.
\end{abstract}

Electronic supplementary material The online version of this article (doi:10.1007/s12230-016-9561-1) contains supplementary material, which is available to authorized users.

Eva Edin

eva.edin@slu.se

1 Department of Forest Mycology and Plant Pathology, Swedish University of Agricultural Sciences (SLU), P.O. Box 7026, 750 07 Uppsala, Sweden

2 Department of Ecology, Swedish University of Agricultural Sciences (SLU), P.O. Box 7044, Uppsala 750 07, Sweden
Resumen El cáncer del tallo en brotes en germinación de la papa a menudo es causado por inóculo de la semilla del hongo Rhizoctonia solani. No obstante, se han encontrado grandes cantidades de nematodos fitoparásitos de vida libre en áreas del campo de plantas de papa con cáncer del tallo. Se pueden usar tratamientos de fungicidas en los tubérculos-semilla para evitar el cáncer del tallo causado por el inóculo de la semilla pero se desconoce si los nematodos pueden afectar esto. Para investigar si los nematodos fitoparásitos de vida libre, el nematodo lesionador Pratylenchus penetrans, o una combinación de varios géneros de nematodos fitoparasitos en una comunidad completa de nematodos, pudieran tener un efecto negativo en el tratamiento de fungicidas a la semilla, se desarrolló un experimento en macetas con tubérculos-semilla inoculados con $R$. solani, la mitad de los cuales se trataron con fungicidas. El inóculo en la semilla causó daño severo a las plantas, mientras que no se observaron daños en las plantas tratadas con fungicidas. Esto muestra que los nematodos no afectan al tratamiento con fungicidas. La probabilidad de costra negra disminuyó en los tratamientos con la comunidad completa de nematodos, lo cual pudo deberse a la acción de nematodos que se alimentan de hongos.

Keywords Pratylenchus penetrans $\cdot$ Rhizoctonia solani . Solanum tuberosum $\cdot$ Stem canker

\section{Introduction}

Stem canker, black scurf and other symptoms caused by the plant pathogenic fungus Rhizoctonia solani Kühn are considered as major problems for potato growers in Sweden, especially in conventional growing systems, which often 
have short crop rotations. The fungus may be soil-borne as it can survive on harvest residues in the soil or be seed-borne when it is present on the seed tubers as sclerotia (black scurf) (Carling et al. 1989). Both inoculum sources may cause stem canker on the germinating potato sprouts. The incidence of seed-borne inoculum is effectively controlled by treating the seed tubers with fungicides prior to planting in conventional farming. The seed treatments are mainly contact fungicides that constrain the fungus that otherwise would have followed the germinating sprouts and roots and later caused disease. Seed treatments do not protect against soil-borne inoculum even though the fungicide may diffuse into the closest rhizosphere and may protect against the closest soil-borne inoculum (Mats Andersson, Bayer CropScience, personal communication). The efficacy of fungicide treatment has not been associated with any negative impact of nematodes but it is fundamental to rule out if nematodes feeding on the seed tuber may reduce the effect of the fungicide treatment.

Plant-parasitic nematodes are present in all soils worldwide and represent $15 \%$ of the total number of nematode species described and are significant pathogens in agriculture (Decraemer and Hunt 2013). Free-living plant-parasitic nematodes are mobile during their entire life-cycle, either in the soil (ectoparasites) or in the roots (endoparasites). Most of the free-living plant-parasitic nematodes have a vast host range, including potato. The role of the free-living plantparasitic nematodes are probably underestimated since aboveground symptoms or misshaped tubers seldom are prominent and they may just delay the development of the plant. Root-lesion nematodes, endoparasitic free-living nematodes, may reduce tuber yield by $12 \%$ and even more if they are followed by secondary infections by fungi and bacteria (Dale and Nielson 2006).

Free-living plant-parasitic nematodes are abundant in patches of stem canker in Swedish potato fields (Andrae 2012; Björsell 2015; A. Kronhed, Lovanggruppen AB, personal communication). There are hypotheses that nematodes and fungi may interact in invading the plant but the mechanisms are unraveled. For example, nematodes may react to the exudates from the fungal infected plants or the fungus may penetrate the plant cortex through the wounds caused by nematode feeding (Back et al. 2002). If the latter is the case, it is then also possible that the fungus could enter into wounds on fungicide treated tubers.

The aim of the project was to determine the effect of freeliving plant-parasitic nematodes, either as a full nematode community or the root-lesion nematode Pratylenchus penetrans, on the fungicide treatment of seed tubers inoculated with $R$. solani. The plants were grown under controlled conditions in a growth chamber. The hypothesis was that the nematodes do not diminish the fungicide efficacy but are able to infest the growing parts of the potato plants.

\section{Material and Methods}

\section{Organisms}

\section{Potato}

Mini-tubers produced from meristem cultures of the cultivar King Edward VII were purchased from Agrico Nordic, but they were cultivated at The Finnish Seed Potato Centre Ltd. (SPK), Tyrnävä, Finland. Cultivar King Edward VII was chosen due to its high susceptibility to $R$. solani and potato cyst nematodes. The tubers were pre-germinated in a glasshouse, $18^{\circ} \mathrm{C}$, until planting so that the sprouts were approximately 3 to $6 \mathrm{~mm}$.

\section{Fungus}

An isolate of Rhizoctonia solani, anastomosis group 3 (AG3), originating from Vara, Sweden, was kindly provided by Dr. S. Ahlström at the Department of Forest Mycology and Plant Pathology, SLU, Uppsala, Sweden. One small piece of mycelium growing on half strength potato dextrose agar (PDA) was added to each of ten petri dishes containing $20 \mathrm{ml}$ half strength potato dextrose broth (PDB) and was incubated on the bench for a week. At inoculation, the filamentous mycelium was harvested and washed with phosphate-buffered saline buffer (PBS). The liquid was pressed out and the mycelium was weighed to correspond to $0.1 \mathrm{~g}$ per tuber and aseptically chopped thoroughly with a scalpel to achieve as small pieces as possible. The mycelium was then suspended in $100 \mathrm{ml}$ of tap water.

\section{Nematodes}

Two types of nematode treatments were used: either the rootlesion nematode Pratylenchus penetrans or a natural occurring full nematode community containing a mixture of nematode feeding groups but dominated by plant-parasitic nematodes. The full nematode community was derived from soil collected in a potato field and the soil was stored cold $\left(4{ }^{\circ} \mathrm{C}\right)$ until nematode extraction. The field was located in the county of Östergötland in the middle part of Sweden. The nematodes were extracted with Whitehead and Hemming trays (Whitehead and Hemming 1965). After $24 \mathrm{~h}$, the water from the trays was poured into glass beakers, put in $4{ }^{\circ} \mathrm{C}$ for sedimentation, after which the amount of water was reduced and gathered in a $3 \mathrm{~L}$ glass beaker. Until inoculation, the beaker with the nematode suspension was stored cold $\left(4^{\circ} \mathrm{C}\right)$ and aerated with an aquarium air pump (SuperFish Air-Flow mini). Prior to inoculation, the concentration of plantparasitic nematodes in the suspension was determined by counting the number of plant-parasitic nematodes in five $2 \mathrm{ml}$ samples in a counting disc. During inoculation, three samples were taken out to determine the composition of the nematode community added to the pots. 
The root-lesion nematode $P$. penetrans was purchased from Plant Research International, Wageningen, the Netherlands, as second stage juveniles. Until inoculation, the nematodes were kept in pots containing maize grown in sterilised sand. To get the nematode inoculum, the plants were harvested, the roots washed and cut into small pieces, and then the nematodes were extracted in trays as described above for the full nematode community.

\section{Experimental Setup}

The experiment was designed as a pot experiment with seven treatments and eight replicates: 1) control, 2) inoculated seed tuber, 3) inoculated seed tuber and the root-lesion nematode $P$. penetrans, 4) inoculated seed tuber and a full nematode community, 5) fungicide treated seed tuber, 6) fungicide treated seed tuber and the nematode $P$. penetrans, 7) fungicide treated seed tuber and a full nematode community (Table 1). Two plant-parasitic nematodes per g potting medium were added in all nematode treatments.

All seed tubers, except for the control, were submerged in the mycelium suspension and carefully taken up so that mycelium was attached to the surface of the seed tuber. The seed tubers for the control were instead submerged in tap water. All seed tubers were placed on paper tissue, the tubers for the control separated from the others, and incubated in a moist cabinet with 16/8 h light cycle for three days at a temperature of $12{ }^{\circ} \mathrm{C}$. The tubers for the fungicide treatment were then dipped in the fungicide solution Monceren FS 250 (a.i. pencykuron $250 \mathrm{~g} \mathrm{~L}^{-1}$, Bayer CropScience, Monheim, Germany) and left to dry in the growth cabinet until planting the next day.

Pots $(12 \times 12 \times 25 \mathrm{~cm}$, drainage holes covered with filter paper) were filled with $1600 \mathrm{~g}$ of washed, sterilized sand (0 to $3 \mathrm{~mm} \varnothing ; 200{ }^{\circ} \mathrm{C}$ for $6 \mathrm{~h}$ ) and $200 \mathrm{ml}$ of tap water was added. One seed tuber was placed in each pot and covered with $960 \mathrm{~g}$ sterilized sand. The pots were then watered with $200 \mathrm{ml}$ of tap water. Both types of nematodes were added in $15 \mathrm{ml}$ of water suspension to each pot, respectively, while the other pots received $15 \mathrm{ml}$ of tap water. The pots were placed in a randomized complete block design under artificial light (152 LUX in average) and moved once a week to provide a uniform exposure of light. The temperature in the growth chamber was set to $12{ }^{\circ} \mathrm{C}$. The pots were watered with tap water twice a week to ensure moist sand and fertilized on three occasions with a complete fertilizer (Blomstra N:P:K 100:18:86, Cederroth AB, Upplands Väsby, Sweden). In total, each plant received $290 \mathrm{mg} \mathrm{N}$.

\section{Harvest}

The pots were harvested block wise, starting eleven weeks after inoculation. The plant was taken out of the pot and the sand was removed. The plant was carefully washed and divided into stems, roots, stolons and tubers. The tubers were divided into small ( 0.5 to $2 \mathrm{~cm}$ in diameter) and large $(>2 \mathrm{~cm}$ in diameter) tubers. The plant parts were graded regarding nematode damage, stem canker, sclerotia and "elephant hide" (brown tuber epidermis, often with crackles) (Supplementary Table 1). The submerged part of the main stem (from the seed tuber up to the surface level, 5 to $8 \mathrm{~cm}$ ), the largest daughter tuber and approximately $1 \mathrm{~g}$ of roots were weighed separately and put in plastic bags for cold storage $\left(4^{\circ} \mathrm{C}\right)$ until later extraction of nematodes. The remaining plant parts were weighed and dried in $75{ }^{\circ} \mathrm{C}$ for $48 \mathrm{~h}$ and the dry weight was recorded. The seed tuber was measured in length and diameter and graded regarding nematode damage and sclerotia (black scurf). Twenty grams of the sand was placed in cold storage until later extraction of nematodes, while another $100 \mathrm{~g}$ of sand was dried in $105^{\circ} \mathrm{C}$ for $24 \mathrm{~h}$ for determination of water content.

\section{Nematode Extraction}

For nematode extraction, the plant material and sand were placed on vlieseline filters (Freudenberg Performance Materials, Weinheim, Germany) in mesh net sieves. The below ground part of the main stem and the roots were cut into $1 \mathrm{~cm}$ pieces and the tubers were divided into four pieces and placed skin side down. If the tuber was large, two sieves were

Table 1 The experimental treatments

\begin{tabular}{|c|c|c|c|c|c|c|}
\hline No. & Name & Abbreviation & Fungus & Fungicide & P. penetrans & Nem. community \\
\hline 1 & Control & $\mathrm{C}$ & & & & \\
\hline 2 & Inoculated seed tubers (IST) & $\mathrm{F}$ & $\mathrm{X}$ & & & \\
\hline 3 & Inoculated seed tubers and Pratylenchus penetrans & $\mathrm{FPp}$ & $\mathrm{X}$ & & $\mathrm{X}$ & \\
\hline 4 & Inoculated seed tubers and full nematode community & $\mathrm{F} \mathrm{NC}$ & $\mathrm{X}$ & & & $\mathrm{X}$ \\
\hline 5 & Fungicide treated IST & $\mathrm{Fc}$ & $\mathrm{X}$ & $\mathrm{X}$ & & \\
\hline 6 & Fungicide treated IST and Pratylenchus penetrans & $\mathrm{Fc} P \mathrm{Pp}$ & $\mathrm{X}$ & $\mathrm{X}$ & $\mathrm{X}$ & \\
\hline 7 & Fungicide treated IST and full nematode community & $\mathrm{Fc} \mathrm{NC}$ & $\mathrm{X}$ & $\mathrm{X}$ & & $X$ \\
\hline
\end{tabular}


used. The sieves were placed in Baermann funnels, and the nematodes were extracted for $24 \mathrm{~h}$, heat-killed and fixated in formalin (Viketoft et al. 2005). The numbers of plant-parasitic and fungal-feeding nematodes were estimated in the suspensions from each extraction under low magnification $(50 \times)$ and expressed as numbers of nematodes per gram dry weight of each plant part or per gram dry soil.

The composition of the nematode community in the three suspension samples taken out during the inoculation of the pots was determined microscopically under higher magnification $(200 \times)$.

\section{Statistical Analyses}

Effects of additions of fungus and nematodes on dry weight of stems, tubers, roots and stolons were analyzed with randomized complete block design ANOVA followed by Tukey adjusted multiple comparisons using R version 3.1.1 (R Core Team 2013). Robust standard errors, packages multcomp (Hothorn et al. 2008) and sandwich (Zeileis 2004, 2006) were used to account for extreme values and heteroscedasticity. Number of tubers and stems were analysed with Poisson regression using $\mathrm{R}$, with the control treatment used as baseline followed by Tukey adjusted multiple comparisons to investigate differences in numbers among the treatments. The proportion of small tubers were analyzed with binomial regression using SAS for Windows 9.3 (SAS Institute Inc., Cary, NC, USA).

To analyze the effect of fungal and nematode damage we used a dichotomous variable - damage or no damage. The data was analyzed with binomial regression using $\mathrm{R}$. The number of nematodes in the different plant parts and in the sand were analyzed with randomized complete block design ANOVA in $\mathrm{R}$ with robust standard errors. Both the numbers of plant-parasitic and fungal-feeding nematodes were analyzed, as they both can affect the performance of $R$. solani.

\section{Results}

The fungicide treatment was effective rendering the growing plants free of disease symptoms caused by $R$. solani. The nematodes did not affect the fungicide protection of the tubers or other plant parts (Table 2). Plant-parasitic nematodes were present in all plant parts and sand samples from the pots where nematodes had been added, both in the treatments with $P$. penetrans and in the treatments with a full nematode community (Table 3). Plant-parasitic nematodes dominated the inoculated nematode community (53\%) and consisted of the genera Pratylenchus (51\%) and Tylenchorhynchus (1.4\%), and the family Trichodoridae $(0.7 \%)$. Bacterial-feeding nematodes were also common (41\%), while root-hair feeders $(2.8 \%)$, fungal feeders $(2.4 \%)$, omnivores $(0.7 \%)$ and 
Table 3 Abundances of plant-parasitic nematodes (PPN) and fungal-feeding nematodes (FFN) (no. gram ${ }^{-1}$ dry weight; mean (SE)) in different parts of potato plants subjected to different combinations of the plant pathogenic fungus Rhizoctonia solani $(\mathrm{F})$, fungicide treatment (Fc), the root-lesion nematode Pratylenchus penetrans (Pp) and full nematode community (NC). Different letters indicate significant differences $(p<0.05)$

\begin{tabular}{|c|c|c|c|c|c|c|c|c|}
\hline \multirow[t]{2}{*}{ Treatment } & \multicolumn{2}{|c|}{ No. in stems } & \multicolumn{2}{|c|}{ No. in tubers } & \multicolumn{2}{|l|}{ No. in roots } & \multicolumn{2}{|l|}{ No. in sand } \\
\hline & PPN & FFN & PPN & FFN & PPN & FFN & PPN & FFN \\
\hline F Pp & $212(147)$ & 0 & $2.22(1.49)$ & 0 & 3011 (1058) a & 0 & $0.20(0.05)$ & 0 \\
\hline F NC & $84(33)$ & $179(67)$ & $9.71(5.88)$ & 0 & 700 (323) a & $336(87) \mathrm{a}$ & $0.17(0.06)$ & $1.71(0.44) \mathrm{a}$ \\
\hline $\mathrm{Fc} P \mathrm{p}$ & $165(53)$ & 0 & $2.55(1.68)$ & 0 & $6156(1000) b$ & 0 & $0.14(0.04)$ & 0 \\
\hline $\mathrm{Fc} \mathrm{NC}$ & $120(36)$ & $10(6)$ & $0.07(0.07)$ & 0 & $1659(660) \mathrm{a}$ & $33(15) b$ & $0.04(0.02)$ & $0.22(0.08) \mathrm{b}$ \\
\hline
\end{tabular}

predators $(0.5 \%)$ were much less abundant. The fungalfeeding nematodes consisted of the genera Aphelenchus (1.2\%) and Aphelenchoides (1.2\%). At harvest, only Pratylenchus spp. was found in the stems, tubers and roots, while the other plant-parasitic nematodes were found together with Pratylenchus spp. in the sand from the full nematode community treatments. Fungal-feeding nematodes were found in the sand as well as in stems and roots of the potato plants from the full nematode community treatments.

\section{Damage on Stems and Stolons}

There were no differences in nematode damage, stem canker or sclerotia on stems among the treatments with fungal inoculated seed tubers (Table 2). In addition, there was no effect of treatment on the number of plant-parasitic nematodes or fungal-feeding nematodes in stems (Table 3). However, the abundance of fungal-feeding nematodes tended to be affected by treatment ( $p=0.08)$ with higher abundance in stems originating from fungal inoculated seed tubers compared to stems originating from fungicide treated seed tubers $(p=0.017)$.

The dry weight of stems was significantly affected by treatment ( $\mathrm{df}=6, \mathrm{~F}=3.23, p=0.011$, Table 4). The root-lesion nematodes $P$. penetrans in combination with fungal infection reduced the growth of stems compared to the control ( $p=0.0099)$ and fungicide treated seed tubers $(p=0.007)$. The plants in the treatment with inoculated seed tubers had more stems compared to the control $(p=0.042)$, even though they did not differ in dry weight (Table 4$)$.

Nematode damages were observed on almost all stolons in the nematode treatments and sclerotia were present on the majority of the stolons in the treatments with fungal inoculated seed (Table 2). The dry weight of stolons were significantly affected by treatment ( $\mathrm{df}=6, \mathrm{~F}=5.64, p=0.0002$ ), but stolons were not recovered in every pot due to severe fungal damage. The dry weight of stolons was lower in the treatments with inoculated seed tubers in combination with the rootlesion nematode $P$. penetrans compared to all the fungicide treated plants (Table 4). Pratylenchus penetrans also reduced the growth of stolons of the fungicide treated plants compared to the stolons of plants from fungicide treated seed tubers without nematodes $(p=0.009)$.

\section{Damage of Tubers}

All daughter tubers from the fungicide treated seeds were free from damages of $R$. solani, whereas the majority of the daughter tubers deriving from the inoculated seed tubers were covered by sclerotia and occasionally also "elephant hide" (Table 2). The likelihood of black scurf on the tubers was lower for the fungal infected plants grown together with the full nematode community than for the plants deriving from fungal inoculated seed grown with the root-lesion nematode $P$. penetrans $(p=0.005)$ or without nematodes $(p=0.008)$.

Table 4 Dry weights (g; mean $\pm \mathrm{SE}$ ) ) and numbers of different parts of potato plants subjected to different combinations of the plant pathogenic fungus Rhizoctonia solani $(\mathrm{F})$, fungicide treatment $(\mathrm{Fc})$, the root-lesion nematode Pratylenchus penetrans $(\mathrm{Pp})$ and full nematode community (NC). Different letters indicate significant differences $(p<0.05)$

\begin{tabular}{llllll}
\hline Treatment & No. of stems & Biomass of stems & Biomass of stolons & Root biomass & No. of tubers \\
\hline C & $2.0 \pm 0.2 \mathrm{~b}$ & $2.60 \pm 0.16 \mathrm{a}$ & $0.112 \pm 0.024 \mathrm{abc}$ & $0.48 \pm 0.02 \mathrm{a}$ & $4.6 \pm 0.7 \mathrm{ab}$ \\
F & $3.8 \pm 0.5 \mathrm{a}$ & $1.69 \pm 0.36 \mathrm{ab}$ & $0.079 \pm 0.016 \mathrm{bc}$ & $0.34 \pm 0.07 \mathrm{ab}$ & $2.5 \pm 0.4 \mathrm{~b}$ \\
F Pp & $3.3 \pm 0.6 \mathrm{ab}$ & $1.48 \pm 0.40 \mathrm{~b}$ & $0.059 \pm 0.018 \mathrm{c}$ & $0.29 \pm 0.07 \mathrm{~b}$ & $3.1 \pm 0.8 \mathrm{ab}$ \\
F NC & $3.4 \pm 0.5 \mathrm{ab}$ & $1.80 \pm 0.35 \mathrm{ab}$ & $0.066 \pm 0.016 \mathrm{bc}$ & $0.33 \pm 0.07 \mathrm{ab}$ & $3.0 \pm 0.8 \mathrm{ab}$ \\
Fc & $2.1 \pm 0.3 \mathrm{ab}$ & $2.60 \pm 0.17 \mathrm{a}$ & $0.171 \pm 0.019 \mathrm{a}$ & $0.50 \pm 0.03 \mathrm{a}$ & $4.9 \pm 0.4 \mathrm{ab}$ \\
Fc Pp & $2.3 \pm 0.4 \mathrm{ab}$ & $2.15 \pm 0.16 \mathrm{ab}$ & $0.099 \pm 0.010 \mathrm{~b}$ & $0.38 \pm 0.01 \mathrm{~b}$ & $4.3 \pm 0.5 \mathrm{ab}$ \\
Fc NC & $2.8 \pm 0.3 \mathrm{ab}$ & $2.26 \pm 0.17 \mathrm{ab}$ & $0.129 \pm 0.026 \mathrm{ab}$ & $0.40 \pm 0.03 \mathrm{ab}$ & $5.6 \pm 0.8 \mathrm{a}$ \\
\hline
\end{tabular}


Damages of nematodes were only found in the treatments with P. penetrans (Table 2). However, there was no significant effect of treatment on the number of plant-parasitic nematodes in the tubers and fungal-feeding nematodes were not recovered from any of the tubers (Table 3).

Addition of fungus had a significant effect on the number of tubers as the fungal inoculated seed tubers gave fewer daughter tubers than the control (Poisson regression: $p=0.027$, Table 4 ). In the multiple comparison, the fungicide and nematode community treatment had more tubers than the inoculated seed treatment $(p=0.04)$, but the proportion of small tuber was not affected by either treatment. In addition, the dry weight of tubers differed among the treatments $(\mathrm{df}=6$, $\mathrm{F}=4.12, p=0.002$ ). The combination of fungal seed inoculum and either nematode treatment reduced the tuber yield compared to the control (Fig. 1). The fungal infected plants in combination with the full nematode community had lower tuber yield than all the treatments with fungicide treated plants, even in presence of nematodes. Also, the fungicide treated plants had higher tuber yield than the plants deriving from inoculated seed tubers in combination with the rootlesion nematode $P$. penetrans.

\section{Nematodes in Roots and Potting Medium}

There were differences among the treatments in the number of plant-parasitic nematodes in the roots $(\mathrm{df}=3, \mathrm{~F}=7.44$, $p=0.0014$, Table 3). Pratylenchus penetrans was more abundant in fungicide treated plants compared to the fungal infected plants $(p=0.03)$. In addition, P. penetrans was more efficient in entering the roots compared to the plant-parasitic nematodes in the full nematode community as the number of plant-parasitic nematodes was lower in both treatments with the full nematode community than in fungicide treated plants with $P$. penetrans ( $p<0.001$ for both). Furthermore, the number of fungal-feeding nematodes in the roots differed between the treatments $(\mathrm{df}=1, \mathrm{~F}=9.17, p=0.019)$, with more fungalfeeding nematodes in the roots originating from inoculated seed tubers compared to roots originating from fungicide treated tubers $(p=0.0026)$ (Table 3).

Necrotic stripes were present on the roots in the majority of the nematode treatments and almost all plants regardless of treatment had brown discoloration of the roots. The vast majority of the roots had sclerotia if originating from a fungal inoculated seed tuber, hence no significant differences (Table 2). The different treatments affected the dry weight of roots ( $\mathrm{df}=6, \mathrm{~F}=2.82, p=0.02)$. The root biomass was lower in both treatments with $P$. penetrans than the fungicide treatment only $(p<0.05$ for both comparisons, Table 4). The roots of the control had higher biomass than the roots of the plant inoculated with both $P$. penetrans and fungus $(p=0.02)$.

There tended to be an effect of treatment on the number of plant-parasitic nematodes in the potting medium $(\mathrm{df}=3$, $\mathrm{F}=2.89, p=0.06$, Table 3). There were less nematodes in the sand of pots with plants originating from fungicide treated seed tubers and a full nematode community compared to the two treatments of inoculated seed tubers with either $P$. penetrans ( $p=0.03$ ) or full nematode community $(p=0.048)$. There were also more fungal-feeding nematodes in the sand of pots with inoculated seed tubers compared to fungicide treated tubers $(p=0.0013)$.

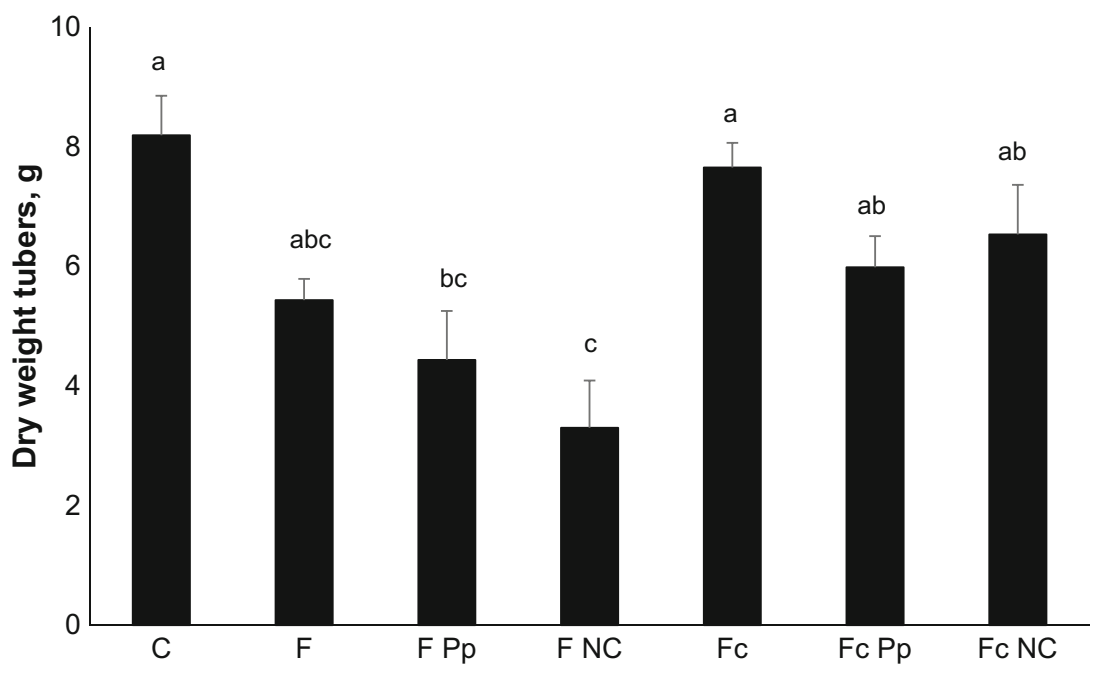

Fig. 1 Dry weight (g; mean \pm SE) of tubers of potato plants originating from seed tubers inoculated with the plant pathogenic fungus Rhizoctonia solani, half of which had been treated with fungicide. The plants were then subjected to plant-feeding nematodes, either as Pratylenchus penetrans or as a full nematode community containing plant-feeding nematodes. Different letters indicate significant differences $(p<0.05) . \mathrm{C}=$ control, $\mathrm{F}=$ inoculated seed tuber, $\mathrm{F}$ $\mathrm{Pp}=$ inoculated seed tuber and the root-lesion nematode P. penetrans, $\mathrm{F} \mathrm{NC}=$ inoculated seed tuber and a full nematode community, $\mathrm{Fc}=$ fungicide treated inoculated seed tuber, $\mathrm{Fc} \mathrm{Pp}=$ fungicide treated seed tuber and the nematode $P$. penetrans, $\mathrm{Fc} \mathrm{NC}=$ fungicide treated seed tuber and a full nematode community 


\section{Discussion}

The inoculation of $R$. solani on the seed tubers was successful in order to cause disease on the entire submerged plant, whereas the fungicide treatment did inhibit the fungus to infect the newly developed plant parts. Neither of the nematode treatments ( $P$. penetrans or a full nematode community) had any effect on the efficacy of the fungicide treatments against $R$. solani, as hypothesized. In addition, the fungicide did not have a reducing effect on the number of nematodes in the plant, which has been observed for root knot nematodes (Walker 1994). Instead, P. penetrans was more abundant in the roots of the fungicide treated plants. The number of plantparasitic nematodes in the stems and tubers were not affected by treatment, even though nematode tuber damages were only found in the treatments with P. penetrans. Despite no visible damages, the nematodes entered the plant tissue regardless of being fungicide treated or not. This leads to reproduction of the nematodes, resulting in higher nematode populations for the successive crops.

Although not affecting the fungicide treatment of seed tubers, the plant-parasitic nematodes affected the potato plants in other ways. The roots of the fungicide treated plants were less discolored but $P$. penetrans reduced the root biomass compared to the control and fungicide only treatment, which may have an effect on the yield if grown to mature harvest. Both nematode treatments in combination with the fungus had a growth reducing effect on the biomass of stems and tubers compared to the control and fungicide only treatment, but no interaction was found. The effect of free-living plant-parasitic nematodes on the yield is not so well studied but Pratylenchus neglectus may reduce the tuber yield if present in high number in the soil (Olthof 1990).

It would have been interesting to analyze the number of plant-parasitic nematodes in the seed tubers since the research question was about the effect of nematodes on the efficacy of the fungicide treatment but that was not possible due to severe degradation. Instead, we assumed that the number of plant-parasitic nematodes was very low, if present at all due to the low abundance of plant-parasitic nematodes in the daughter tubers.

Fungal-feeding nematodes were surprisingly found inside stems and roots but did not seem to inhabit the daughter tubers. They were more abundant in the plants from inoculated seed tubers than in the plants from fungicide treated seed tubers, most likely due to good food availability. The same pattern was observed for the abundance of fungal-feeding nematodes in the potting medium. The fungal-feeding nematodes are not known to inhabit plant parts but were probably attracted to the fungus and followed the mycelium into the stems and roots where the fungus caused deep damages. The fungus did not enter the tubers, except for the tubers with "elephant hide" where the skin was damaged, and this could explain why fungal-feeding nematodes were not recovered from the tubers.

In the present study, the nematodes in the full nematode community had a negative impact on the likelihood of black scurf on the tubers, which may be due to the presence of fungal-feeding nematodes. The question is if this could be applied in natural soils. Fungal-feeding nematodes may serve as biological control agents of soil-borne fungi in particular and thereby decrease the infection risk on germinating sprouts. Both the genera Aphelenchus and Aphelenchoides have been shown to suppress damping-off caused by $R$. solani in cauliflower seedlings and enhance the diseasesuppressive effect of compost (Friberg et al. 2005; Ishibashi 2005; Lagerlöf et al. 2011). It is an interesting topic and more research is needed for implementation in practical potato cropping system.

Besides causing disease symptoms on the potato plants, plant growth was affected by the fungus in other ways too, since the number of stems was higher in the fungal infected plants compared to the control. The plant may produce more sprouts to ensure proper growth when sprouts are highly affected by stem canker (Lehtonen et al. 2008). The stem biomass had not increased but the plants were rather young at harvest compared to an ordinary potato crop.

In conclusion, this pot experiment showed that free-living plant-parasitic nematodes do not inhibit the fungicide effect of pencykuron. However, free-living plant-parasitic nematodes may negatively affect the growth and yield of potato plants by their direct feeding on the plant.

Acknowledgement We thank Annhild Andersson for maintaining the experiment and for counting the nematodes. Johanna Jernberg helped us during harvest and the statistical calculations were kindly performed by Jonas Kardell. This work was supported by The Swedish Farmers' Foundation for Agricultural Research under Grant H1142045.

Open Access This article is distributed under the terms of the Creative Commons Attribution 4.0 International License (http:// creativecommons.org/licenses/by/4.0/), which permits unrestricted use, distribution, and reproduction in any medium, provided you give appropriate credit to the original author(s) and the source, provide a link to the Creative Commons license, and indicate if changes were made.

\section{References}

Andrae, L. 2012. Förekomsten av frilevande nematoder $i$ västsvenska jordar och deras inverkan på potatisens kvalitet avseende rost (TRV) och Rhizoctonia solani. Research and Development: En forrstudie. Report to the Swedish Board of Agriculture In Swedish.

Back, M.A., P.P.J. Haydock, and P. Jenkinson. 2002. Disease complexes involving plant parasitic nematodes and soilborne pathogens. Plant Pathology 51: 683-697. 
Björsell, P. 2015. Interactions between some plant-parasitic nematodes and Rhizoctonia solani in potato fields. In Agricultural Programme - soil and plant science. Uppsala: Master's thesis, Department of Ecology, SLU.

Carling, D.E., R.H. Leiner, and P.C. Westphale. 1989. Symptoms, signs and yield reduction associated with rhizoctonia disease of potato induced by tuber-borne inoculum of Rhizoctonia solani AG-3. American Potato Journal 66: 693-701.

Dale, M.F.B. and R. Nielson. 2006. Research review: free-living nematodes and spraing. British Potato Council Research Review, pp 162.

Decraemer, W., and D.J. Hunt. 2013. Structure and classification. In Plant nematology, ed. R.N. Perry and M. Moens, 3-39. Wallingford: CAB International.

Friberg, H., J. Lagerlöf, and B. Rämert. 2005. Influence of soil fauna and fungal plant pathogens in agricultural and horticultural systems. Biocontrol Science and Technology 15: 641-658.

Hothorn, T., F. Bretz, and P. Westfall. 2008. Simultaneous inference in general parametric models. Biometric Journal 50: 346-363.

Ishibashi, N. 2005. Potential of fungal-feeding nematodes for the control of soilborne plant pathogens. In Nematodes as biocontrol agents, eds. P.S. Grewal, R.U. Ehlers and D.I. Shapiro-Ilan, 467-475. Wallingford: CABI Publishing.

Lagerlöf, J., V. Insunza, B. Lundegårdh, and B. Rämert. 2011. Interaction between a fungal plant disease, fungivorous nematodes and compost suppressiveness. Acta Agriculturae Scandinavica Section B Soil and Plant Science 61: 372-377. doi:10.1080/09064710.2010.488655.

Lehtonen, M.J., P. Somervuo, and J.P.T. Valkonen. 2008. Infection with Rhizoctonia solani induces defense genes and systemic resistance in potato sprouts grown without light. Phytopathology 98: 1190-1198.

Olthof, T.H.A. 1990. Reproduction and parasitism of Pratylenchus neglectus on potato. Journal of Nematology 22: 303-308.

R Core Team. 2013. R: A language and environment for statistical computing. R Foundation for Statistical Computing, Vienna, Austria. URL http://www.R-project.org/.

Viketoft, M., C. Palmborg, B. Sohlenius, K. Huss-Danell, and J. Bengtsson. 2005. Plant species effects on soil nematode communities in experimental grasslands. Applied Soil Ecology 30: 90-103.

Walker, G.E. 1994. Growth of grapevine rootlings in soil from a field nursery naturally infested with Meloidogyne incognita and Rhizoctonia solani. South African Journal of Enology and Viticulture 15: 26-32.

Whitehead, A.G., and J.R. Hemming. 1965. A comparison of some quantitative methods of extracting small vermiform nematodes from soil. Annals of Applied Biology 55:25-38.

Zeileis, A. 2004. Econometric computing with HC and HAC covariance matrix estimators. Journal of Statistical Software 11: 1-17.

Zeileis, A. 2006. Object-oriented computation of sandwich estimators. Journal of Statistical Software 16: 1-16. 